\title{
Rumen characteristics of grazing dairy cows supplemented with sulla and maize silages in summer
}

\author{
A.V. Chaves ${ }^{1,4}$, G.C. Waghorn ${ }^{2}$, I.M. Brookes ${ }^{3}$ and S.L. Woodward ${ }^{2}$ \\ ${ }^{1}$ Unité Mixte de Recherches Production du Lait (UMRPL), Institut National de la Recherche \\ Agronomique (INRA), 35590, St-Gilles, France \\ ${ }^{2}$ Dexcel Limited, Private bag 3221, Hamilton, New Zealand \\ ${ }^{3}$ Institute of Food, Nutrition and Human Health, Massey University \\ Private bag 11222, Palmerston North, New Zealand
}

\begin{abstract}
This study investigated the effects of silage supplementation of grazing dairy cows. Forage mixtures used in the four week trial with rumen fistulated cows in five treatments enabled rumen sampling to determine effects of diet on rumen parameters. Five groups of ten cows were grazed on a restricted daily allowance of $18 \mathrm{~kg}$ dry matter (DM) pasture/cow, and four groups received sulla silage (S) or maize silage (M) alone or in mixtures to make up $40 \%$ of total intake. A sixth group was given an unrestricted (38 kg DM/cow.day) pasture allowance. Samples of rumen liquor data demonstrated significant effects of supplement.
\end{abstract}

KEY WORDS: dairy cows, maize, pasture, rumen, silage, sulla

\section{INTRODUCTION}

The previous cow study (Woodward et al., 2002) which examined responses to maize, pasture, lotus and sulla silage supplementation showed clear benefits of lotus silage for milk production when pasture supply was restricted. Although maize silage did maintain milk production over the four week experimental period the cows did not gain weight (in contrast to other silages) and the dietary crude protein (CP) was less than cow requirements (NRC, 2001). These silages provided a foundation for further evaluation, with more focus on achieving adequate dietary $\mathrm{CP}$ using fewer silages types.

\footnotetext{
${ }^{1}$ Corresponding author: e-mail: chaves@st-gilles.rennes.inra.fr
} 
Balancing dietary protein deficiency by feeding sulla and improving readily fermentable carbohydrate intake with maize silage may optimize milksolids production from cows grazing poor-medium pasture in summer. The hypothesis to be tested here was that mixtures of maize and sulla silages fed to cows grazing restricted pasture would provide a more balanced diet and compare rumen parameters among treatment diets.

\section{MATERIAL AND METHODS}

Sixty Friesian cows (including 10 with rumen fistulae) were allocated to six treatments and balanced for milksolids yield and liveweight. The overall design comprised a uniformity (covariance) period of one week, when all cows were grazed on pasture enabling their subsequent allocation to six groups to be fed the experimental diets for three weeks.

\section{Treatments}

The six treatments enabled the effects of supplementing a pasture diet with either maize and/or sulla silages to be compared with un-supplemented pasture. The pasture allowance was intended to be $25 \mathrm{~kg} \mathrm{DM} / \mathrm{cow}$ per day, but calculations after sub-division of plots using a visual assessment of pasture mass in the last week of the trial resulted in less herbage DM mass on offer than expected.

1. FP: full pasture allowance ( $38 \mathrm{~kg} \mathrm{DM} /$ cow.day)

2. RP: restricted pasture allowance $(18 \mathrm{~kg} \mathrm{DM} /$ cow.day $)$

3. PMS: pasture (restricted) + maize silage $(4 \mathrm{~kg})+$ sulla silage $(2 \mathrm{~kg})$

4. PSM: pasture (restricted) + sulla silage $(2 \mathrm{~kg})+$ maize silage $(4 \mathrm{~kg})$

5. PS: pasture (restricted) + sulla silage $(6 \mathrm{~kg})$

6. PM: pasture (restricted) + maize silage $(6 \mathrm{~kg})$

\section{Rumen samples}

Rumen fluid was collected 5 times during the first day of the in sacco incubation (data not presented) to check the pattern of rumen metabolite concentration over $12 \mathrm{~h}$ from 07:00 h (pre-feeding) to 19:00 h. On each occasion, about $1 \mathrm{~kg}$ of rumen contents was taken from the mid-ventral rumen and strained though a cheese cloth to collect $100 \mathrm{~mL}$ of rumen fluid. Rumen $\mathrm{pH}$ was determined at collection before samples were centrifuged and prepared to determine ammonia (Chaney and Marbach, 1962) and VFA concentrations (Attwood et al., 1998).

\section{Statistical analysis}

Rumen ammonia and VFA concentrations were analysed using mixed model procedure of SAS (PROC MIXED; SAS, 2001) to calculate treatment means. Rumen $\mathrm{pH}$ analysis included day, treatment and treatment $\mathrm{x}$ day interaction. 


\section{RESULTS}

Rumen liquor $\mathrm{pH}$ (Table 1) averaged across all cows shows higher values $(\mathrm{P}<0.001)$ prior to AM feeding (mean 6.7 \pm 0.1 ) compared to values after the $\mathrm{PM}$ milking $(16.00 \mathrm{~h})$ which averaged $5.6 \pm 0.1$. There was no effect of diets on either morning or afternoon $\mathrm{pH}$, or diurnal pattern.

Table 1. Averaged rumen $\mathrm{pH}$ and concentrations $(\mathrm{mMol} / \mathrm{L})$ of metabolites for cows grazing pasture with and without maize and/or sulla silage supplements

\begin{tabular}{|c|c|c|c|c|c|c|c|}
\hline \multirow{2}{*}{ Diet } & \multirow{2}{*}{$\mathrm{pH}$} & \multirow{2}{*}{$\mathrm{NH}_{3}$} & \multicolumn{5}{|c|}{ Volatile fatty acids } \\
\hline & & & acetate & propionate & butyrate & minor & total \\
\hline Pasture & 6.2 & 11.4 & 70.7 & 17.7 & 11.7 & 4.2 & 104.1 \\
\hline PMS & 6.2 & 5.5 & 65.7 & 15.9 & 9.6 & 3.3 & 94.5 \\
\hline PSM & 6.2 & 7.0 & 71.6 & 17.0 & 10.5 & 3.7 & 102.8 \\
\hline PS & 6.3 & 8.9 & 66.5 & 17.3 & 10.5 & 4.0 & 98.1 \\
\hline PM & 6.0 & 6.1 & 74.0 & 16.7 & 11.0 & 3.7 & 105.4 \\
\hline Mean & 6.1 & 7.8 & 69.7 & 16.9 & 10.6 & 3.8 & 100.9 \\
\hline Diet & ns & $*$ & ns & ns & ns & ns & ns \\
\hline Week & $* *$ & $*$ & $* *$ & ns & ns & ns & $*$ \\
\hline Diet $\times$ week & $\mathrm{ns}$ & ns & $\mathrm{ns}$ & ns & ns & $*$ & ns \\
\hline
\end{tabular}

abbreviations are given in text. ${ }^{\dagger} \mathrm{P}<0.10,{ }^{*} \mathrm{P}<0.05, * * \mathrm{P}<0.01$

Mean concentrations of rumen VFA were similar across treatments, averaged $101 \mathrm{mMol} / \mathrm{L}$, with about 0.69 acetate, 0.17 propionate and 0.11 butyrate (Table 1). There were no treatment effects on concentration or molar proportion of VFA. The ratio of acetate: propionate averaged 4.1 and was similar for all diets. In contrast, the pasture diet resulted in highest concentrations of rumen ammonia (Table 1) and lowest values were measured when maize silage was included in the diet. Cows fed either pasture or pasture plus sulla silage had higher rumen $\mathrm{NH}_{3}$ concentrations than other supplemented treatments $(\mathrm{P}=0.03)$.

The diurnal variation in VFA concentrations showed peak concentrations about $6 \mathrm{~h}$ after morning feeding. The diurnal range in total VFA concentrations was greatest with the PM diet and least with PMS. Dietary effects on the extent of diurnal variation was similar for acetate and butyrate but diets containing sulla appeared to have least diurnal variation in concentrations of minor VFA. Ammonia concentrations followed a similar diurnal pattern as VFA but the variation was much smaller with PMS and PSM, than other diets. This can be explained by grazing behaviour because cows fed PMS and PSM chose to eat supplements first, followed by pasture while cows given PS or PM grazed pasture first and ate supplements after grazing. 


\section{DISCUSSION}

Diets did not affect concentration or molar proportions of VFA (Table 1). The $84 \%$ increase in dietary NSC concentration when maize silage was added to pasture did not affect either propionate concentration or acetate: propionate ratio. In contrast cows fed pasture as a sole diet had a higher concentration $(\mathrm{P}<0.02$; Table 1) of ammonia compared to other diets.

Although there were no effects of diet on rumen VFA, diets with pasture, maize and sulla silages (PMS and PSM treatments) provided a stable rumen environment possibly due to feeding behaviour. The lower variation over the $12 \mathrm{~h}$ period from 07.00-19.00 $\mathrm{h}$ for VFA was also evident for $\mathrm{NH}_{3}$, probably because the cows given these treatments ate supplements first (PMS and PSM) and then grazed pasture. Cows grazed pasture first with PM and PS diets. The PMS treatment was the most acceptable diet for the cows, with least refusals and provided the highest NSC dietary concentration. Visual observations suggest the cows preferred mixtures of sulla and maize silages compared with either silage fed alone, but the short duration of the trial and restricted pasture availability prevented further evaluation of silage effects on total DMI or performance.

\section{CONCLUSIONS}

The dietary mixtures of maize and sulla silage did reduce diurnal variation in rumen fermentation parameters. Future progress to maximize milk production from cows grazing pasture and supplemented with silages should investigate the ability of diets to alter fermentation rate and be nutritionally balanced. Studies should also test both low and high pasture allowances to obtain information on choice of nutrient from pasture versus the supplement. This information will provide a better understanding of substitution than can be obtained with a single pasture allowance and a focus on choice and cow behaviour may provide a better understanding of rumen stability and cow performance.

\section{REFERENCES}

Attwood G.T., Klieve A.V., Ouwerkerk D., Patel B.K.C., 1998. Ammonia-hyperproducing bacteria from New Zealand ruminants. Appl. Environ. Microbiol. 64, 1796-1804

Chaney A.L., Marbach E.P., 1962. Modified reagents for determination of urea and ammonia. Clin. Chem. 8, 130-132

NRC, 2001. National Research Council. Nutrient Requirement of Dairy Cattle. 7th revised Edition. National Academy Press, Washington, DC

SAS, 2001. SAS/STAT User's Guide, Version 8.02. Statistical Analysis System Institute, Inc., Cary, NC Woodward S.L., Chaves A.V., Waghorn G.C., Laboyrie P.J., 2002. Supplementing pasture-fed dairy cows with pasture silage, maize silage, Lotus silage or sulla silage in summer- does it increase production? Proc. N. Z. Grassl. Assn. 64, 85-89 